\title{
Sheppard Sunderland Frere Historian and Archaeologist
}

Born 23 August 1916; died 26 February 2015

\section{TRIBUTES}

Professor Sheppard Frere, one of the leading scholars of Roman Britain and the founder of our journal Britannia, died earlier this year at the age of 98. At the scheduled meeting of the Britannia Editorial Committee, which was held soon after his death, it was agreed that this volume of the journal should be dedicated to Sheppard and should also include a tribute incorporating a number of voices, which reflected the longevity of his vast contribution to and influence on the development of Romano-British studies. Those who have contributed - and there could have been many others - have not only recorded his many achievements, but also recalled numerous anecdotes that characterise the man so well.

\section{A PERSONAL MEMOIR ${ }^{1} B y$ Roger Goodburn, Oxford}

Sheppard was born at Graffham near Petworth in Sussex on 23 August 1916. He was the eldest of three sons, and the family came from East Anglia, where his great-great-great-grandfather was John Frere of Roydon, of palaeolithic Hoxne fame. As with many of the family, Sheppard's father Noel worked in the colonial service, mainly in Sierra Leone.

Sheppard's prep school was Earlywood at Ascot. When he first arrived there in his Aunt Joan's Model-T Ford, he remembered being embarrassed because everyone else had come in Rolls Royces or Bentleys. He started Latin and Greek there, but did not enjoy being forced to have Greek lessons by post in the holidays. He did, however, then win a scholarship to Lancing, where he became interested in archaeology, and where B.W.T. Handford, to whom Britannia is dedicated, had founded the archaeological society. This was named for Francis Haverfield, who had once taught there. When the boys were 'turned out of doors on Sunday afternoons', Sheppard's choice was to explore nearby sites such as Park Brow, Cissbury Ring and Lancing Roman temple, which also kindled his interest in ancient ceramics. He used Curwen's books, which he said he found 'inspirational'. Later, he got to know the Curwens, Elliot and E.C. On one occasion he was invited to lunch, during which old Mrs Curwen asked Sheppard: 'Are you Saved?' to which, uncharacteristically indecisive, he mumbled 'I don't know', which did not go down very well.

1 Based on tributes delivered at Sheppard's Funeral in All Saints Church, Marcham on 12 March 2015 and the Memorial Service in All Souls College, Oxford on 16 May 2015. 
He read Classics and Ancient History at Magdalene College, Cambridge. There, the Master, A.B. Ramsay, made his scholars do 'saying lessons', i.e. learning a Greek or Latin text, adding twenty lines more each week. Even in 1935 this was considered old-fashioned, but Sheppard never regretted his learning by heart. Even though Demosthenes evaporated over the years, he could to his latter days recite long pieces of the Aeneid and the writings of Tacitus. In his early reading, Sheppard's critical faculties were already sharp: in one of his books the opinion of an eminent scholar is quoted, and receives Sheppard's marginal note 'But it is well-known that he ought to be locked up'. In the undergraduate archaeological society he made friends with Rainbird Clarke and dug for Grahame Clark at Peacock's Farm, a Mesolithic-Neolithic site near Mildenhall. He also went digging in 1938, not, as was fashionable, with Mortimer Wheeler at Maiden Castle, but with Gerhard Bersu at Little Woodbury. He was much influenced by Bersu's 'revolutionary leadership'.

After Cambridge, he taught at Epsom College (1938-40), where he founded the school archaeological society and had his first involvement in Surrey archaeology. He excavated at Highdown (in Sussex) with A.E. Wilson and later at the Chatley Farm, Cobham villa (sometimes with the help of his brother David). He also became honorary editor of the Surrey Archaeological Collections.

In 1939 Sheppard excavated with Kathleen Kenyon at the Wrekin, and was given the challenging daily task of driving the ancient expedition car, laden with provisions, up the steep, grassy slopes to the summit. During his war service in London, K.K. encouraged him to make a map and survey of bombed sites in Southwark; while doing this he came close to being arrested as an enemy agent, but disentangled himself by getting the authorities to ring Philip Corder at the Society of Antiquaries. K.K. also encouraged Sheppard to organise the Sussex, Surrey and Kent Regional Group of the newly formed Council for British Archaeology.

S.S.F.'s training in methods of excavation derived mainly from Bersu (Little Woodbury), K.M. Kenyon (the Wrekin, Southwark) and A.E. Wilson (Highdown). He never worked with Wheeler, but adopted Wheeler's method of relating stratigraphical layer numbers through section layer-labels and note-book entries. He also used Wheeler's draughtsmanship as a model, but developed his own style. His training in ancient history was a powerful influence, persuading him of the need to tie archaeology with history as far as possible.

He found occasional opportunities to go and dig on bombed sites in Canterbury with Audrey Williams, and when she moved to Verulamium Museum in 1946, he was invited to direct the Canterbury excavations. At the same time he began teaching at Lancing. During the school holidays (Christmas included) he excavated in Canterbury and returned to school each term with tea-chests of finds to be sorted and drawn in his spare time. During term, ex-pupils recount that setting them work in class gave him the opportunity to keep up his reading of Antiquity \&c. ... His move to Lancing was particularly fortunate because he became a housemaster and met the sister of one of his prefects - Janet, whom he married in 1961.

Sheppard's university career began in 1954, when he briefly held the post of Lecturer in Archaeology at the University of Manchester. In 1955 he succeeded Mortimer Wheeler at the London Institute and became Reader in the Archaeology of the Roman Provinces. He could now concentrate fully on his work in archaeology. The first of his seven seasons of excavation at Verulamium took place in that same year and he continued work at Canterbury until 1960. S.S.F.'s teaching in the Archaeology of the Western Provinces led to the writing of his history of Roman Britain, Britannia.

His long-standing interest in late prehistory included numerous excavations, mostly in Britain, but also at the hillfort of Charlat in the Corrèze, with Molly Cotton. Also, together with Derek Allen, he started up the national index of Iron Age coins. But as time elapsed, archaeology became increasingly complex and increasing specialisation was necessary. S.S.F. accordingly concentrated his interests increasingly on the Roman period. After the War, he had become a 


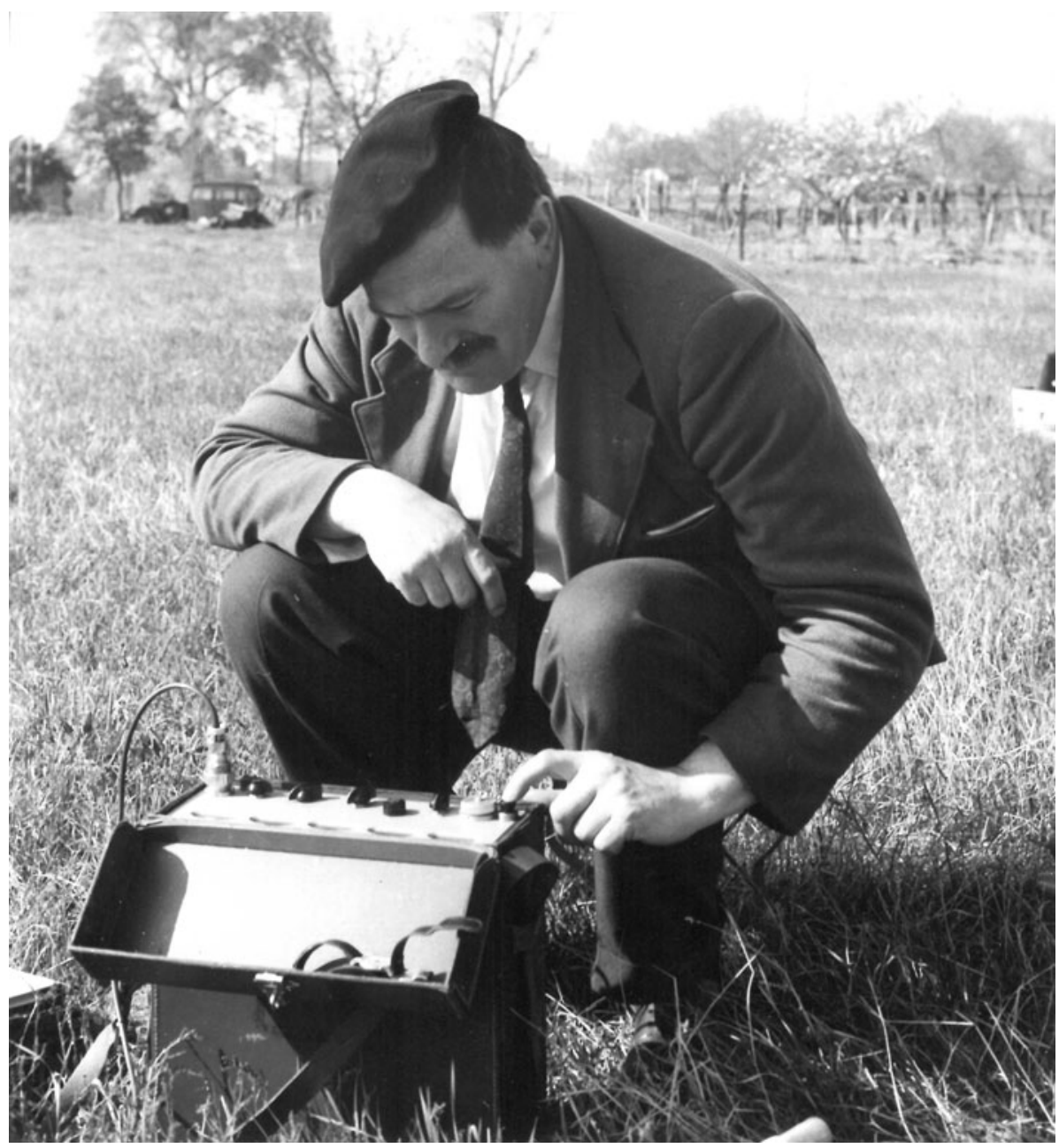

FIG. 1. Sheppard Frere at Lezoux in 1961. (Photo courtesy of Janet Frere)

close friend of Ian Richmond, whom he identified as an important formative influence on his thinking. He also owed much to his friendship with Brian Hartley, with whom he discussed his work and excavated at Lezoux.

In 1966 Sheppard was invited to Oxford University to take up the Chair of the Archaeology of the Roman Empire, which he held until 1983, with a Fellowship at All Souls College. His teaching in London had included splendid lectures on Gaul and Germany. Now it included more easterly provinces, as far as the Euphrates. During this time, the family extended warm hospitality to many visiting academics, including some from the eastern bloc. The cultural differences there were illuminated by one professor who arrived and was shown up to his room, but failed to appear for supper. Eventually Sheppard went and knocked on his door, which was opened by a figure clad in pyjamas ... He thought that he had been sent to bed!

On the other hand, during a visit to the East to give a lecture, he deposited his brief-case in the office before being taken to inspect various sites. On returning at the end of the day, he suddenly 
remembered the case. The reply 'What case?' led to Sheppard's comment that someone had presumably had the later use of a jolly good lecture.

His various expeditions to Gaul had a gastronomic aspect: one conference fed by the catering college near Strasbourg resulted in his triumphal return home with the chef's recipe for a superb dessert, with which Janet delighted many of their guests. In Germany, his excavation at Xanten alongside those of the Bonn Museum employed current British methods. The German workmen were amazed by the holes and protuberances which Sheppard's site produced; their finely-honed shovels always produced a beautifully even surface in the sandy soil for each $5 \mathrm{~cm}$ level, whatever the archaeology ... The weather was extremely hot, and the early-morning glass of schnapps proffered by the men drew his response 'Glorious oblivion!' He sometimes had to 'check some proofs' in the site hut.

The publication of his Verulamium and Canterbury excavations were heavy tasks and even S.S.F.'s capacity for sustained hard work did not allow him to diversify as far as he would have wished into other fields of the Roman Empire. His interests accordingly remained centred largely on Roman Britain.

Sheppard's interest in the Roman army was illustrated by a number of excavations such as Bowes (with Brian Hartley) and Longthorpe (with Kenneth St Joseph). In 1973 he was invited to direct the Scottish Universities Field-School of Archaeology in succession to Anne Robertson, who had excavated at Birrens and Cardean. The site now chosen was the fort at Strageath, near Crieff. The excavations lasted until 1986, nine of the seasons under Sheppard's direction. At a reception for the well-wishers of the excavations, including Lady Jane, the landowner, and $\mathrm{Mr}$ Brown, the tenant farmer, Sheppard was distributing to the company glasses of sherry from a tray. When he came to Mr Brown and asked would he care for a glass of sherry, Mr Brown swiftly eyed the tray and exclaimed, 'Ah'm a whisky man'. So Sheppard dug in his pocket, went to the bar and produced the dram. The guiding committee arranged for evening lectures by various distinguished visitors. One notable occasion was when Kenneth St Joseph flew into Scone and went over to the Cultoquhey Hotel to talk about his new discovery of Durno, probably Agricola's camp on the eve of mons Graupius.

His draughtsmanship was superb - derived especially from Ian Richmond and partly from Wheeler. Janet was sometimes roped in to provide architectural drawings. (Her inclination to digging, however, was limited to Bignor.)

Sheppard's formal retirement from Oxford University brought little change in the volume of his archaeological labours. In 1988 Frank Lepper and he produced a book about the reliefs on Trajan's Column in Rome. They describe it in the preface as an 'old man's book', backing up their claim by saying that on a trip to Bucharest in 1979, they were mistaken for participants in a geriatric convention; but they did follow this up by hoping that their reader (quote) 'will detect more evidence of mature wisdom than of senile amnesia'.

Britannia, first published in 1967, has maintained its indispensability through four editions over 50 years. He said recently that 'it was a lot of hard writing'. Down the years, sometimes an enquiry on some point would prompt him to say 'What does Frere say?' and sometimes, leafing through, 'damn good book this'. It is; and when in the 1990s he was approached by the Folio Society asking whether he knew of an important book which they ought to republish, his confident reply was 'Mine!'. (They did.)

Other writing continued and one of his very recent productions was a stout defence and justification of one aspect of his interpretation of the Verulamium discoveries.

Sheppard had a great ability to grasp the essentials of a question. In Britannia (1st edn, 1967, 34), he discussed Caesar's campaigns in Kent and suggested that the Roman camp built after the capture of Bigbury would perhaps be found at Harbledown. As recently as October 2010 he came to supper, bringing the new Kent Archaeological Newsletter 86. Placing it on the table, he opened it at page 15 to show a LiDAR picture of polygonal earthworks on Harbledown, described there as 
the object of Caesar's assault. He didn't speak, but having also had the newsletter that day, I responded 'Caesar's Camp!' He grinned. Doubtless time will tell.

Sheppard always kept himself abreast of current work, which included many visits to excavations. His reputation pretty well always guaranteed a warm reception. On one occasion, however, a young lady who clearly did not recognise him, extended a rather frosty greeting when he appeared on site. On enquiring for the director, and being asked who he was, mention of his name instantly electrified the said young lady and she hurtled off to find the boss. Sheppard grinned and said 'I do rather enjoy it when that happens'.

Some of his last visits were to the current excavations at Dorchester-on-Thames. Having excavated there in 1962-3, he was gratified to see what the new areas beyond some of his trenches were revealing - and at one point to enquire courteously whether more sections might be useful ...

Sheppard was a great scholar, a great friend.

VERULAMIUM By William Manning, Emeritus Professor of Roman Archaeology, Cardiff University

In the years after the Second World War, the majority of rescue excavations were dependent on 'volunteers', usually sixth-formers and university students with an interest in archaeology. Sheppard Frere's excavations at Verulamium were among the largest of their time and digging at Ver, as the site was always called, was a rite of passage for many aspiring archaeologists in the 1950s. It was there in 1959 that I first met many of the people whose careers in archaeology have run parallel with my own, among them Barry Cunliffe, Geoff Dannell, Ros Dunnett (Ros Niblett), Mark and Tom Hassall, Alan McWhirr, David Neal and Malcolm Todd.

Most of the volunteers camped in a field near the site in conditions which were distinctly basic. A cook was employed to prepare meals of a fairly simple type, which were eaten in a large hut that served as the communal centre of the excavation. There was an earth-latrine with canvas walls and the river Ver provided all the facilities needed for washing.

I dug at Verulamium twice. The first time was for a couple of weeks in 1956 as one of a group of four undergraduates from Nottingham University. The second time was in 1959 when I was studying under Sheppard at the Institute of Archaeology in London. On that occasion I worked as a site supervisor, initially on a trench designed to detect what, if anything, had preceded the construction of the Roman theatre, and then on a section through the bank behind the city wall. Sheppard gave his supervisors a considerable amount of independence, visiting outlying trenches, such as those on which I worked, perhaps twice a day, although he kept a closer eye on the more complex central areas. He used his majestic but ancient Rolls Royce to reach the more remote trenches; a vehicle which acquired a mythology of its own among his students. At the end of the day's work the finds were taken to a large room above a block of changing-rooms near the museum. There, seated at the top of the external stairs, Sheppard would examine the contents of the trays, throwing the sherds which were of no interest onto a rapidly growing monte testaccio at the foot of the staircase. Verulamium was typical of many of the excavations of the mid-twentieth century in that the faunal remains were not routinely kept, owing in large part to the dearth of experts in that field. Sheppard's rather casual attitude to them was reflected in his reply to my question on beginning work in 1959, 'What animal bones should I keep?', which got the reply, thrown over his shoulder as he left the theatre - 'Oh, keep the unusual ones. Keep the kangaroo bones'.

The excavation of 1955 had revealed a deep, early Roman defensive ditch running across the site and in 1959, Martin Aitken agreed to use the newly developed proton magnetometer to try to 
trace it across the city. At that time it was still far from certain if the magnetometer could consistently detect ditches and pits. Sheppard felt that, as someone who had been trained as a scientist, I would be a suitable assistant on the survey, and, together with Ros Niblett, we followed the course of the ditch across the park. Martin Aitken was puzzled by the fact that at one point it vanished only to reappear a few metres further on, but, as Sheppard delightedly pointed out to me, this proved that the magnetometer actually worked, for the break was at the point where Watling Street would have crossed the ditch.

As a post-graduate student at the Institute, and later as the specialist responsible for the report on the iron objects, I saw something of the post-excavation side of the work, and here the contrast between the past and the present is perhaps most striking. For most of the time Marion Wilson, who was his deputy on the excavations and who catalogued and drew most of the coarse pottery, was the only person paid (a pittance, I suspect) to work on the excavated material. Later other illustrators were employed to draw the small finds and, when he moved to Oxford, Sheppard had research assistants to help him, but he not only wrote almost all of the site reports but drew almost all of the plans and sections himself. This was, of course, typical of the period; what was different was the scale of the project and it is a tribute to his single-minded devotion that he saw the three volumes of the report through to completion.

RIB II: INSTRUMENTUM DOMESTICUM By Dr Roger Tomlin, Emeritus Fellow, Wolfson College, Oxford

Forty years ago Sheppard Frere, for whom I had dug at Bowes, came into my office in the Department of Classics, Durham, where I had just replaced Richard Wright as Lecturer in Roman History, and asked me to join Wright and Mark Hassall in editing the annual 'Roman Britain: Inscriptions' chapter for his new journal Britannia. Despite already being a subscriber, I had never thought of becoming an epigraphist of Roman Britain, but I agreed at once, naïvely stipulating that it should not interfere with my research, which was then into the late Roman army. Well, of course it did interfere, and on the whole I have been grateful to Sheppard ever since. Only once did I visit a new inscription with Wright, but by studying his work I soon came to share the true epigraphist's obsession with minutiae, which nonetheless would marry surprisingly well with Sheppard's unique drive and energy.

But this was more than ten years in the future. Meanwhile Richard Wright, who had published the first volume of RIB in 1965, worked devotedly on the second in every hour he could spare from digging his garden and allotment. This second volume would at last collect the 'non-monumental' inscriptions of Britain, the graffiti and other inscriptions not on stone which epigraphists quaintly call Instrumentum Domesticum, all those found before the end of 1956. In due course Sheppard would characteristically extend this cut-off point by another thirty years, to the end of 1986 . The volume was based upon the 'Roman Britain: Inscriptions' chapters which had appeared every year since 1921 in JRS, and in Britannia since 1970, but the archive which it generated already filled a whole room in Wright's house in Victoria Terrace, Durham. There was box after box of reused brown envelopes full of drawings and rubbings, plaster casts and paper squeezes, letters from the great of Romano-British archaeology and the not-so-great, folders full of arcane interim reference-numbers, a huge card-index meticulously maintained ... altogether a daunting but essential accumulation. Only Wright knew his way around it, but despite the saving garden and allotment, his health and energy began to falter, and in 1986 by prior arrangement Sheppard descended on Victoria Terrace with his big Volvo. Instead of the usual picks and shovels, ranging-poles and tobacco, he crammed it with boxes and files representing many years of work, not only by Wright himself but by the great R.G. Collingwood in Oxford, 
whose beautiful handwriting was everywhere. He was the founding-editor of $R I B$, but the project dated further back still to Mommsen's protégé Francis Haverfield, who like Sheppard himself was a sometime schoolmaster at Lancing College who became an Oxford professor.

Thus RIB II returned to Oxford, where by coincidence I had preceded it, to lecture on the Confessions of St Augustine in the Faculty of Modern History. To bring the project to its long-awaited conclusion, Sheppard first proposed himself as my 'research assistant', but fortunately I heard no more of this, and we soon came to a much better arrangement: he would transcribe and edit Wright's files and I would check his draft against the drawings and other material he sent me. The plan of the work would follow the prospectus in RIB I, but the idea of writing introductions to the sections, for example 'Lead Sealings' in the first fascicule, was entirely his own. It was I who suggested, for better or worse, that we divide the work into fascicules so as to ensure a steady output, but the overall planning was all by him. As he later said, with self-deprecation far short of the truth, he only provided the necessary 'managerial ruthlessness'. It was altogether due to his drive and energy, as I have said already, that the project was completed in seven years. In successive Prefaces drafted for our sponsors, the Administrators of the Haverfield Bequest, he generously acknowledged the help and co-operation of others, the most important contributors being Margaret Roxan, who edited the military diplomas in the first fascicule despite her distaste at being told to conflate both texts, inner and outer, and Mark Hassall, the first editor of many items, who was belatedly promoted to the title-page in the sixth fascicule.

Unfortunately I kept no written records of our collaboration, and I can find very little in the archive, since draft entries with my annotations were returned to Sheppard and these formed the basis of the text sent to Alan Sutton in Stroud, whence they emerged as proofs which we duly returned. At frequent intervals I would receive another thick, square envelope full of handwritten sheets. I was in awe of this industry, which I checked as carefully as I could, altering a word here and there, occasionally adding a note of my own, and (I must add, since I am writing about a great man, not a saint) sometimes reminding him of the difference felt by epigraphists between square brackets and round brackets. But as the years went by, he was forever embracing labour from which I would have fled, not only drafting those many, many transcripts, but fair-copying all those tissue-paper rubbings and those endless plaster casts. He doggedly calculated the variation between the actual weight and the theoretical weight of Roman lead weights, for example, his introduction to this section being praised by an early reviewer as 'immensely instructive'. And so it was, like his many other introductions, which I still use as my first point of reference.

If Sheppard had been less modest, he might have said, like the Duke of Wellington, that it would not have been done if he had not been there. I know this, if anyone does, so let me put those words into his mouth. Thank you again, Sheppard.

THE 'PROFESSOR' By Francis Grew, Archive Manager, Museum of London Archaeological Archive

When I think of Sheppard Frere - whom, incidentally, I never addressed as anything other than 'Professor', a more familiar form of appellation seeming inappropriate from one who had been his Research Assistant - I always recall a sunny afternoon at Brandon Camp. While Holy Joe scrabbled away, desperately searching for a granary delineated on an aerial photograph, Sheppard and I lounged in the grass, our feet dangling over the trench side. 'What a splendidly amateur dig this is', he said contentedly. His ease with the world came partly from the fact that we had recently completed lunch. With satisfaction I savoured the compliment paid to the sandwich filling I had procured from the local grocer. 'Such a noble slice of ham!' 


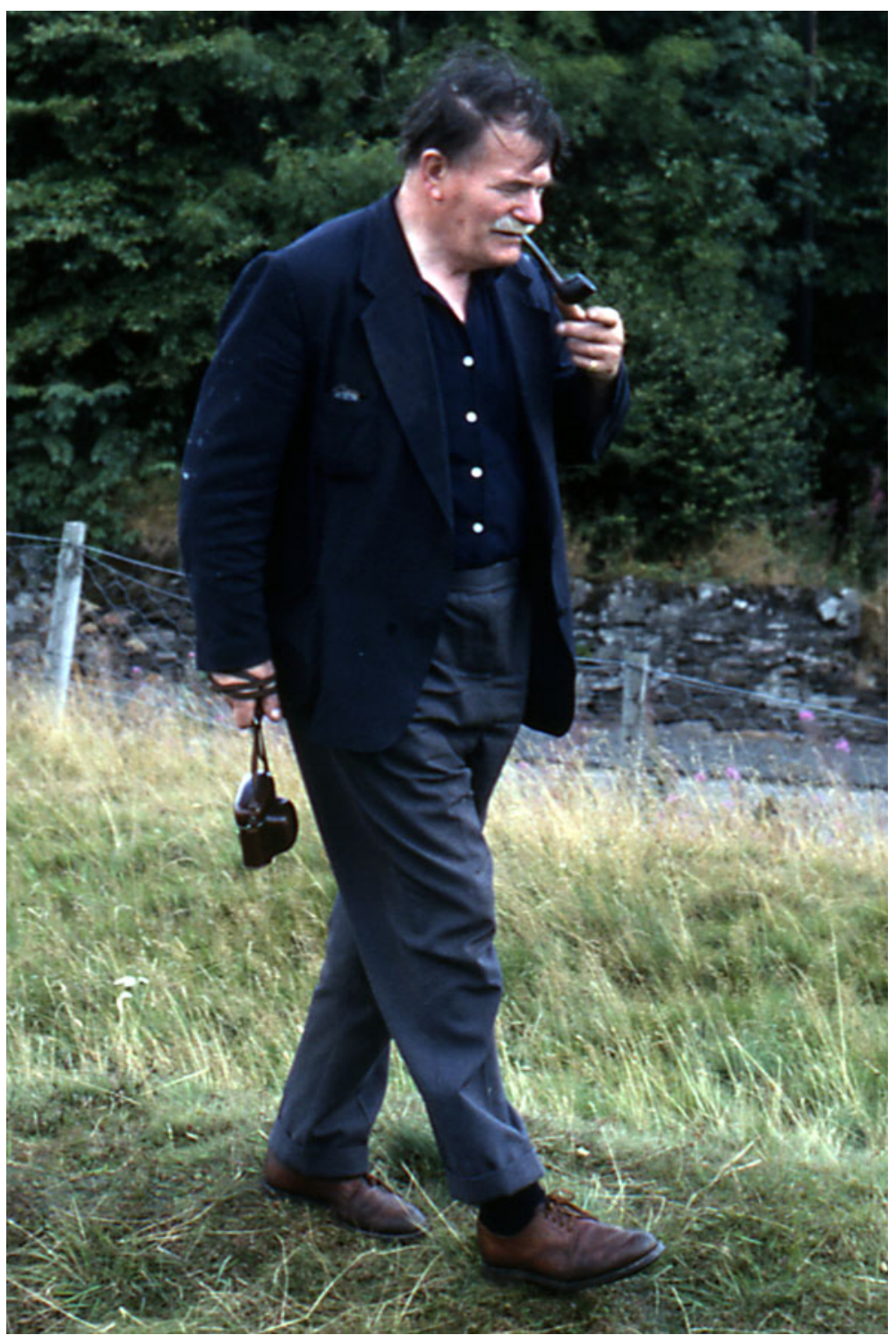

FIG. 2. Sheppard Frere on the site of the Roman fort at Ardoch in 1980. (Photo: Francis Grew)

I suspect that Sheppard was at his happiest when on a dig. He approached it with the enthusiasm of a schoolboy released from the Latin form and was a superb fieldworker, equally adept at spotting in a landscape the faint undulations that denoted a rampart and ditch, as at distinguishing the subtle variations in texture and colour of an ephemeral post-hole. Not all aspects of archaeology fascinated him of course. Take animal bone, for example — 'We all know the Romans had sheep and cows' - or quantitative studies of coarse pottery. The best use for DR20 amphora sherds was as packing beneath the wheels of his Volvo when it got stuck in the mud. 
One of Sheppard's gifts was that he was just as effective when directing large teams of students or volunteers as when digging alone with one or two assistants. Thus the end-of-day site tours were a particularly notable feature of life at Strageath. I picture him now, ranging-pole in hand, poking at - even 'proddling', to use one of his favourite expressions - the latest discoveries and enthusiastically explaining how much we were learning about Roman strategy in Scotland. As an apprentice supervisor, I found Sheppard an excellent teacher. He could be ruthless in his estimation of a student's ability — 'Good diggers', he once told me, 'are born not made' but was adept at deploying the less skilful in a way that neither caused offence nor wasted their energy. 'Look at that man', I remember him saying, 'the best you can do is give him one of those big pits to dig out. He can't do any damage there'. On another occasion, at the start of the season, I was horrified to discover that a visiting Professor of Archaeology had been assigned to my trench. 'How ever can I find him a suitable task?', I asked in despair. 'Give him a shovel and tell him to get on with it', was the sensible answer.

After dinner, and often a lecture, Sheppard's evenings at Strageath were spent checking the page proofs of the journal Britannia and compiling the index. Buying standard index cards would have been deemed far too extravagant, and so he used hundreds of little slips of paper. Some carried crossings-out, and it is entirely possible that they had been reused from the year before. Critics have said that Sheppard published too little, especially in the 1970s, but in truth he channelled so much of his energy - almost anonymously — into creating a journal that was world-class, not only in the quality of its scholarship but also in the standards of its production.

In his writing, Sheppard prized clarity and simplicity above anything else. Incorrect syntax and punctuation insulted the reader, he believed, because they usually led to ambiguity. Consequently, his copy-editing was so relentless that it has become legendary. Having studied Latin and English grammar from a very early age, I escaped the worst of his strictures, but when I was charged with editing the annual round-ups for Britannia, he gave me a firm lesson on how to go about it. Deep in concentration, pipe clenched between his teeth, his red pen had barely advanced a line before I heard a muttering, 'b****** doesn't understand that a compound adjective like "second-century" must be hyphenated'. A few words on, it was a chuckle - 'Perhaps the $b^{* * * * * *}$ thinks the emperor's fourth declension' — as he gleefully added a final 's' to make a genitive of 'Claudius'. As the pen confidently scored out whole lines, replacing them with just a few words that were far more effective, I timorously enquired whether such treatment might offend the contributor. 'Words cost money', was the response - and I have never forgotten it.

As many others have observed, memories of Sheppard do often concern food. There was, for instance, the occasion when we drove down to Bignor - ostensibly to work on the excavation report that would be published in Britannia in 1982 - and stopped to have lunch with the Tuppers, who owned the site. Sheppard was offered a plate of ham. 'Ahhh, excellent', he said, 'home killed and cured I'm sure'. 'Well no', replied Mrs Tupper, 'it comes from the local shop'. 'Pity', was the gruff response. 'Ham was the main reason for coming here'. The threat of withholding his lunch was in fact one of the few strategies that could be used to defeat Sheppard, as I would discover some years later. He and I were working in the dining room at Marcham on the ironwork from Strageath; Janet and my wife, Sara, were in the kitchen. Concentrating on the x-rays, I was only dimly aware of Sheppard stealthily leaving the room with several large, thoroughly hydrated, bags of silica gel. His plan was to refresh them in the oven. Sara, a feisty Scot, was evidently standing guard in the kitchen. 'Do you have PERMISSION to do that?', I heard. 'If those things go in the oven, there will be NO LUNCH'. Clearly beaten, Sheppard slunk back into the dining room.

The last occasion I saw the Professor was at his ninetieth birthday party. As I said my goodbyes and wished him well, he looked me up and down, and spoke just a few words. 'Francis', he said, 'I believe you have something for me in the boot of your car'. He was referring, of course, to my 
report on the military metalwork from his excavations at Bowes in the $1960 \mathrm{~s}$ - and, needless to say, I had neither brought nor completed it. For the next two days, and at least part of the nights, I worked on the report; then posted it and telephoned to check that it had arrived. 'I am so sorry', I began, 'to have been, as usual, the last to submit my report'. 'No, no', he interrupted, 'you are the first. I must now get on to those $\mathrm{b}^{* * * * * * *}$ about the animal bones!'.

MEMORIES FROM A FORMER STUDENT AND RESEARCH ASSISTANT By Dr Lynn Pitts, Publications Secretary, Society for the Promotion of Roman Studies

Having grown up in St Albans, it was with excitement and trepidation that I found myself one of Professor Sheppard Frere's students at Oxford - this was the eminent archaeologist who had excavated Verulamium. My intended DPhil topic was to develop my earlier study of bronze figurines, but at the outset Sheppard mentioned the possibility of writing-up Richmond's work at Inchtuthil, followed by 'But it probably won't interest you'. This was clearly what he thought I should do; involvement with Strageath and later Brandon followed.

Sheppard was a demanding supervisor, he expected his students to gather evidence meticulously and present it well but in return he would always read drafts thoroughly and spend time discussing finer points. Boris Rankov remarked that 'one of the key aspects of having Sheppard as a supervisor was his expertise with all types of evidence, being equally at home discussing site reports, texts of Dio or minutiae of Latin epigraphy'. And Sheppard expected his students to attempt a similar expertise. Having studied Classics was an advantage, but I was sent away to learn German before being despatched to Germany to meet Professor von Petrikovits, the expert on legionary fortresses. Inchtuthil ensured that I received more attention than some students recall. In the words of Simon Esmonde Cleary, 'His was a "hands off" approach; if one wanted his support he was very happy to give it, otherwise he was sufficiently trusting and content to let one get on with it'. But his method worked well as any role call of his students demonstrates. Sheppard believed that helping his students get jobs was one of the chief functions of a supervisor and considering how many of his students went on to senior posts in universities and elsewhere, in this he was eminently successful.

All three of his Oxford Research Assistants are contributing here, reflecting the affection and loyalty Sheppard evinced from his staff, many of whom were present at his funeral. When I was Sheppard's RA for his last two years at Oxford, Marion Wilson was still there drawing pottery from his many excavations, having worked for Sheppard since the 1950s. She was kept very busy since he was trying to write up sites before retirement and had several research assistants - myself working on Strageath, Sally Stow on Canterbury and Pam Lowther on Dorchester. Sheppard always treated his staff with respect; Lynda Smithson, who worked as Sheppard's secretary in the Institute and continued to type for him long into his retirement, remembers him as 'always courteous and patient ... and with a surprisingly wicked sense of humour'.

As Francis Grew points out Sheppard always seemed happier and more relaxed on excavation, particularly at Brandon with its smaller numbers. Then he would be prepared to sit and talk and that sense of humour was evident. His ability as a teacher was also on display; he was often to be seen kneeling in the trench at Strageath patiently showing young students how to find and excavate a post-hole; or on the 'educational' trips at weekends striding around one of the Scottish forts, pipe in hand, expounding on the archaeology, including on the lilia at Rough Castle where students were made to stand in the pits to make the layout clear. I always think of Sheppard with his pipe in his hand or pocket (sometimes with smoke drifting from it) - or indeed on the odd occasion using both hands to light it while driving down the motorway! Not the famous Rolls 
Royce; in my time Sheppard drove a Volvo - good for accessing muddy sites in Scotland. With Sheppard the provision of food was an important part of any dig and one of the duties of an RA was to ensure that food supplies were good and plentiful. But at Brandon Sheppard happily took a turn at making tea for the team.

Meticulous attention to detail - in his own work and others - and his vast knowledge, is what made Sheppard such a great editor. One of my first jobs as RA was to check the Verulamium and Roman Britain from the Air proofs - a daunting task as I knew he was reading them too. Later he suggested that I become John Wilkes' assistant on Britannia - and I'm still here trying to maintain the high standards Sheppard set for the journal and monographs. Sheppard put a huge amount of time into Britannia and he considered the Roman Britain Sites section so important that he undertook the collation of material himself for several years after he retired. Sheppard also went on writing articles long into retirement, he was publishing in Britannia and elsewhere until 2011. With each paper that he submitted for Britannia he would remark 'This will be my last'.

Sheppard and Janet enjoyed entertaining at Marcham and ex-students were always welcome, as were their children who would on occasion be allowed to handle Roman coins. Whenever I visited he was keen to discuss the latest books or reports, or to show me plans he was working on — the dining room was always full of drawings and these spread through the house; on one occasion Sheppard went off to find one from 'Janet's wardrobe'. And Sheppard always wanted to know about Britannia and future monograph plans.

ROMANO-BRITISH STUDIES By Michael Fulford, Professor of Archaeology, University of Reading

Sheppard's contribution to Romano-British studies can be considered in perhaps three ways: his contribution to our knowledge and understanding of the period, his contribution to the scholarly infrastructure of Romano-British archaeology and his contribution as a teacher at the three universities where he taught.

With regard to Roman Britain, first and foremost we think of his Britannia: A History of Roman Britain, first published in 1967 but remaining in print to this day in its fourth edition (1999). This was the first major study of Roman Britain since Collingwood's contribution to the Oxford History in 1936, but its architecture was similar, giving priority to a narrative of Rome's engagement with Britain from Caesar to the post-Roman period of the fifth and sixth centuries, which drew on the written and epigraphic sources supported by the archaeology.

For that archaeology to be worthwhile strict attention had to be paid to its execution and recording in the field so that there could be confidence in the chronology derived from the subsequent study of the finds. Against a background where urban studies were still dominated by the antiquarian investigations at Silchester, Caerwent and Wroxeter, with their timeless town plans, dating structures and sequences was all important. Wheeler had begun this approach at Verulamium but he had not gone far enough as Sheppard made clear in his introduction to Verulamium I $(1972,3)$. Publication of the evidence in the form of plans, sections and the detailing of the dating evidence was all important to Sheppard. The seven-year investigation of a swathe of Verulamium (1955-61), including the detailed dissection of a sequence of timber-built tabernae in Insula XIV, set new standards in urban archaeology and provided the basis for a completely new narrative of the town's history. Earlier, as Director of Excavations in Canterbury from 1946, working in the severely bomb-damaged city, he had developed his careful stratigraphic approach, recovering many important aspects of its history and archaeology from the late pre-Roman Iron Age through the Roman and Anglo-Saxon to the later medieval period. His last foray into urban archaeology was to undertake excavations in 1962 and 1963 at 
the small town of Dorchester-on-Thames revealing important evidence of the Roman to Saxon transition.

His meticulous approach was also applied in the Romano-British countryside where he re-excavated the Bignor villa in West Sussex (1956-62) to establish and date the developmental history of the main villa building.

While publication of his work in Canterbury and Verulamium remained a major pre-occupation into the 1990s, the move from the London Institute of Archaeology to the Chair at Oxford in 1966 saw a change of direction from towns to Roman military archaeology where, working in partnership with J.K. St Joseph, whose aerial reconnaissance of Roman Britain was recovering much new evidence, not least of its military occupation, he undertook major rescue excavations of the pre-Flavian, 27-acre fortress and 11-acre fort sequence at Longthorpe, near Peterborough (1967-73), exploring about a third of the larger structure, which he interpreted as accommodating a part-legionary force or vexillation. He saw the use of such units as typical of the modus operandi of the Roman army in the Claudio-Neronian period. Further work, also partly in collaboration with St Joseph, on the pre-Flavian period occurred later at Brandon Camp (1981-5) where the 8-acre Iron Age hillfort had been occupied by a Neronian unit. His first venture into military archaeology had been with Brian Hartley at Bowes on the Stainmore Pass in Yorkshire (1966-7), but this was eclipsed by the major campaign with J.J. Wilkes on the Agricolan to Antonine fort at Strageath, north of the Forth-Clyde isthmus (1973-86), examining a large area, about one fifth, of the successive forts' interiors. In parallel with the prompt publication of Longthorpe, Strageath and Brandon, all achieved by 1989, Sheppard worked with St Joseph on their masterly overview, Roman Britain from the Air (1983), with images which provided a dramatic landscape appreciation of the military conquest and settlement of Britain as well as illuminating urban and rural aspects.

To the infrastructure of Romano-British archaeology Sheppard contributed much, most notably to the establishment of the national journal of 'Romano-British and kindred studies', Britannia, in 1970 which he edited for its first ten years. ${ }^{2}$ Alongside that he led the establishment of the Britannia Monograph series, editing the first ten volumes up to 1989. When colleagues were in short supply to write the 'Roman Britain in 19xx' section, he stepped in to ensure continuity and contributed that section for some ten years following his retirement from the Oxford Chair in 1983. He also co-founded, in 1982, and co-edited for its first three years of publication the Oxford Journal of Archaeology. Elsewhere in this appreciation Roger Tomlin considers another great achievement, their joint publication between 1990 and 1995 in eight fascicules of all the Roman inscriptions from Britain on materials other than stone, representing Volume II of The Roman Inscriptions of Britain. Britannia remains the only province of the Roman Empire where the publication of the Instrumentum Domesticum has been achieved. Sheppard also brought the work of others to publication, notably Atkinson's excavations of the forum-basilica and baths of Caistor by Norwich, Richmond's excavation of the church at Silchester and, finally, his collaboration with Hartley at Bowes fort, published in his 93rd year in 2009. The writing up of all the excavations for which Sheppard was responsible had been completed in the 1990s.

Sheppard's career in archaeology spanned a period which saw a dramatic rise in the number and scale of archaeological excavations, for the most part undertaken in advance of development. While it was practical to publish all the detailed dating and other supporting evidence to accompany his reporting of his Verulamium excavations, the increase in contributions from the rapidly developing specialisms in fields such as archaeobotany and archaeozoology, as well as in aspects of material culture, especially pottery, led to corresponding increases in the size and

2 For Sheppard's own recollections of the birth and growth of Britannia, see S.S. Frere and R. Goodburn, 'Britannia 40 years: Roman Society 100 years', Britannia 41 (2010), 33-5. 
cost of publication. Although not confined to the Roman period Sheppard's chairmanship of the Ancient Monuments Board's working party and his editorship of the subsequent report on the Principles of publication in rescue archaeology: report by a working party of the Ancient Monuments Board for England published by the Department of the Environment in 1975 tried to address the problem of how much and to what level of detail it was appropriate to publish archaeological excavations. Inevitably it shifted the emphasis towards the publication of synthesis and interpretation ('Level 4') rather than on the primary evidence as epitomised by his own publications, Verulamium I-III. It also led to a downgrading of the work of the new generation of specialists, much of which in the 1980s was relegated to microfiche, a now redundant technology. The problem of what to publish still remains very much a live issue though the development of electronic resources now allows for the possibility of making available information which would be unthinkable in printed book or journal-article form.

The third theme of this appreciation is Sheppard as teacher. Although he began his career teaching Classics in the classrooms of Epsom and Lancing College it was in the context of his career both as a University teacher and as an editor that this aspect of his contribution to Romano-British studies can be best appreciated. Many important contributions have flowed from a succession of graduate students, such as Simon Esmonde Cleary, Elizabeth Fentress, Martin Henig, Stephen Johnson, Martin Millett, Lynn Pitts, Boris Rankov, Warwick Rodwell, Roger Wilson and Christopher Young, while others such as Michael Mackensen and Sebastian Sommer took their Anglo-Saxon archaeological training back to Germany. Roger Goodburn, Francis Grew and Bill Manning, who have contributed to this appreciation of Sheppard, also studied under him at various times. As journal and monograph editor and strongly influenced by his training in Classics he was eagle-eyed in his focus on clarity of expression and economy of writing and all who have been subjected to his editorship have benefited greatly from the experience. His rigour was legendary and I well remember the nervousness with which I opened his review of my first article submitted to Britannia in 1972, while my Britannia Monographs 5 and 10 benefited enormously from his editorial pen. 